\title{
Proximate and Organoleptic Test of Strawberries Wet Noodle
}

\author{
Rince Alfia Fadri, Sri kembaryanti Putri, Yenni Muchrida, Rilma Novita, Salvia, Mimi Harni \\ Program Study of Food Technology, Polytechnic of Agricultural, University of Andalas, \\ Payakumbuh, West Sumatera, Indonesia \\ E-mail: rince.alfia@yahoo.co.id
}

\begin{abstract}
Strawberies much contain of phytochemicals, included polyphenols which are reported to reduce cancer risk a coronary heart desease and others degeneratives diseases. These effects are considered as most important to be related to the capacity of polyphenol antioxidant found in strawberries. In connection of this case,then a research to be done to know strawberries potential in its utilization on the making of wet noodle.The purposes of this research are to grade physical quality (include color.aroma,texture and taste) and nutrient quality of strawberries wet nodle. Research type of to be used is "experimental Design" with way of treating different increment strawberries quantity to the each three treatments 50 grams,100 grams and 150 grams also using wet noodle control without strawberries increment. Datas gathering of physical strawberries wet noodleto to do through organoleptic by 20 trained semi panelists. Than, nutrient quality datas to be gotten with proximate wet noodle content analyzing with HPLC methode and also "Nutry Survey" program on computer software. Data analyzing for physical quality t do with ANOVA at significant level 5 percent to be trhough with Duncan's difference test at significant level 5 percent. Than nutrient quality datas descriptively analyzed after to be compared with noodle's nutrient quality without strawberries (control) also wet noodle's nutrient quality that contained in Food Stuff Composition List. Result of this research to show that strawberries wet noodle has good physical quality (at preferred level).treatment to be preferred is wet noodle with the increment of 100gram strawberries. The quality of strawberries wet noodle is also better because contains antioxidant especially polyphenols than to be compared with wet noodle without strawberries (control) and wet noodle in Food Stuff Composition List.
\end{abstract}

Keywords - strawberry; wet noodle.

\section{INTRODUCTION}

\section{A. Background}

Indonesia is one of the countries with a fairly high population, development of population growth followed by a bustle of developments and needs. The development of advances in technology also affect the patterns of life and change consumption patterns and the power increasingly diverse society thought to consume food products, sometimes by not considering whether the product has adequate nutrient content or not, it is now turning to fast food products.

See current opportunities, the food industry seems like to have a race to create instant food products. The noodles are ready-made food products that most fans because the nutrient content of noodles can already suffice as a substitute for rice. Now these noodles not only as suppliers of energy, but also as a source of other nutrients. Various vitamins and minerals can be on substitution and fortification into the noodles. Combination with fruits, vegetables and protein source needs to be done in an effort to boost the nutritional composition of the completeness of the noodles.

The fortification of the fruit in the making of noodles is still a rarity. One of the fresh fruit that can be added is strawberry. Strawberries (Fragaria chiloensis 1.) is a herbaceous plant that average has 200 small seeds per fruit. Some compounds, phytochemicals found in fruit such as strawberries are anthocyanin, ellagik acid, catechins, kuaerferin and kaemferol. One of the functions of the anthocyanin is as an antioxidant in the body so as to prevent the occurrence of atherosclerosis. The addition of strawberries in the making of noodles can create the noodles soaked with flavor and color innovations as well as high nutritional value and contains antioxidants which are very good for health.

In West Sumatra, noodle products have been recognized by the community of wet raw noodles, noodles, dried noodles and instant noodles. Over time the products have undergone developments with variations of a mix between flour as the main raw materials with other materials such as tubers, legumes, vegetables and fruits that can certainly increase the nutrient content of these noodles. 
According to Astawan (2008), noodle is food products made from dough of flour or flour as the main ingredient with or without the addition of other additives. In an effort to diversify food, noodles can be categorized as one of the food commodity substitution because it can serve as a food staple. Wet noodle is a kind of process boiling noodles after cutting stage. Wet noodle is usually marketed fresh in the State. Wet noodle has a distinctive flavor and served and can be blended with other foods so wet noodles more preferred.Because of that, conducted a research to generate innovation in color and flavor of the noodles moist rich antioxidants and frowned upon by society.

\section{B. Formulation Of The Problem}

How the influence of the addition of Strawberry different formulations of proximate analysis results and organoleptic test noodles produced.

\section{The Purpose Of The Research}

To find out the influence of the addition of Strawberry that obtained a good noodle with proximate and organoleptic test. Create Noodles with flavor and new color that has a nutrient content and antioxidant that is better than the existing General noodle products, as well as acceptable to the consumer.

\section{Hypothesis}

There is the influence of the addition of Strawberry that obtained a good wet noodles with proximate and organoleptic tests.

\section{E. Framework Concept}

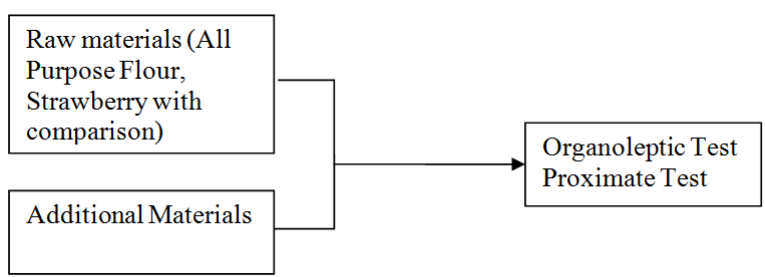

\section{RESEARCH Methodology}

An easy way to comply with the conference paper formatting requirements is to use this document as a template and simply type your text into it.

\section{A. Time And Place}

This research was carried out in August-December 2012 in Processing Laboratory, chemical laboratory at Agricultural Polytechnic State of Payakumbuh and Laboratory of BPOM Padang.

B. Tools And Materials

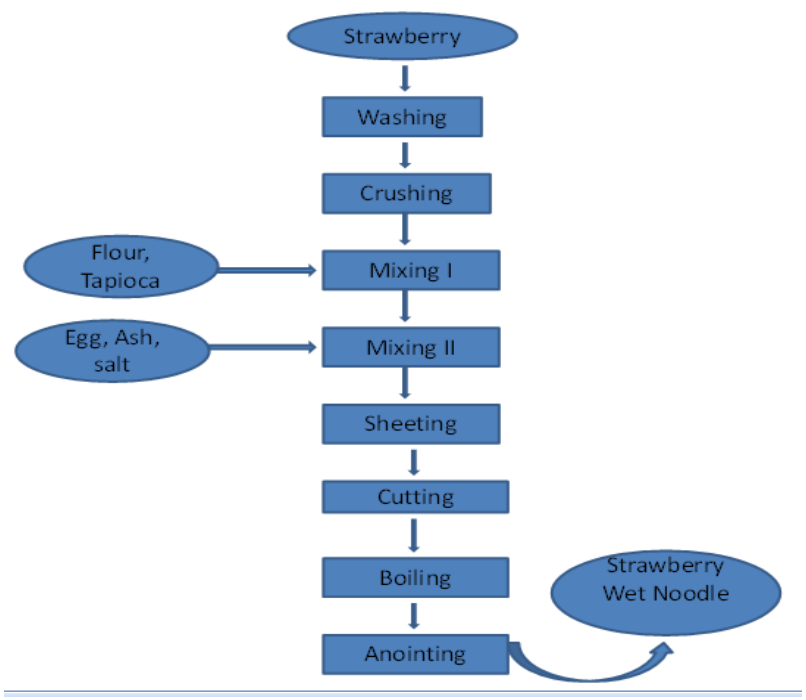

Tools used in this research are the knife, roller, footbath, noodles, pan, stove, sieves, spoon, desiccator, analytic scales, erlenmeyer flask, beaker, grated, bowls, porcelain bowls, stopwatch, mortar, bowl, soxhlet and device, kjhedhal and the device. The materials used in this research are the blue triangle cap flour, strawberries, cooking oil, salt, aquadest, aluminum foil, alcohol, filter paper, Chloroform, $\mathrm{HCL}, \mathrm{NaOh}$, drying roll, clean water, eggs.

\section{Experimental Design}

This research is purely experimental with a Complete Random Design with 3 treatments and 2 times the repetition and the use of control as follows

A. Addition of $50 \mathrm{~g}$ strawberries

B. Addition of $100 \mathrm{~g}$ strawberries

C. Addition of $150 \mathrm{~g}$ Strawberry

D. Control

\section{Data Collection}

Organoleptic Data Test collected for the study of the physical quality of the 20 person of semi trained panelists by filling out the form provided. Nutritional quality Data obtained from the proximate test with HPLC method in the laboratory BPOM Padang and data analysis of the wet noodle nutrients that are converted by DKBM with the help of program nutry survey in the laboratory at Agricultural Polytechnic State of Payakumbuh.

\section{E. Data Analysis}

Organoleptic Data Test include colors, aromas, textures and flavors that have been collected are presented in a frequency table for further analyzed with ANOVA and Duncan test different significance level at 5\%. The result of data processing of wet noodles nutrition quality with analysis treatment descriptively by comparing between the treatments done with control on research. Furthermore the quality of nutrition research results are also compared with the wet noodle nutrition quality in the composition of the Food Stuffs List (DKBM).

\section{RESULTS AND DISCUSSION}

The results shows that the concentration of the addition of pureed strawberries influential to the observed 
parameters. Based on the results of laboratory analysis to find out the test of proximate (nutrient content) of a wet noodle strawberries the most preferred by panelists is the treatment B with the addition of Strawberry $100 \mathrm{~g}$ compared with wet noodles without the addition of strawberries and control is shown in table 1. Effect comparison of the concentration of the addition of Strawberry, without the addition of strawberries on a wet noodle and the wet noodle based the composition of the Food Stuffs List (DKBM) shown in table 2.

TABLE I

Result Of Proximate Analysis On 3 Treatments And Control MAKING Of STRAWBERRIES Wet NOODLE

\begin{tabular}{|l|l|l|l|l|l|}
\hline No & $\begin{array}{l}\text { Nutritional } \\
\text { Composition }\end{array}$ & $\begin{array}{l}\text { Treatmen } \\
\mathrm{t} \\
\mathrm{A}(\%)\end{array}$ & $\begin{array}{l}\text { Treatment } \\
\mathrm{B}(\%)\end{array}$ & $\begin{array}{l}\text { Treatment } \\
\mathrm{C}(\%)\end{array}$ & $\begin{array}{l}\text { Contr } \\
\text { ol } \\
(\%)\end{array}$ \\
\hline 1 & Carbohydrate & 45,78 & 41,44 & 35,46 & 47,29 \\
\hline 2 & Protein & 5,45 & 6,01 & 6,06 & 4,01 \\
\hline 3 & Fat & 0,60 & 0,69 & 1,73 & 1,78 \\
\hline 4 & Water Level & 47,50 & 50,88 & 55,63 & 45,90 \\
\hline 5 & Dust Level & 0,67 & 0,98 & 1,12 & 1,02 \\
\hline
\end{tabular}

Source: Research Results Data of Making Strawberry Noodle, 2012

TABLE II

COMPARISON OF THE NUTRIENTS OF STRAWBERRY WET NOODLE ON

TREATMENT B ( ADDITION 100G OF STRAWBERRY), WET NOODLE

CONTROL (No STRAWBERry AdDITION) Also WeT NoOdLE IN DKBM

\begin{tabular}{|l|l|l|l|l|l|}
\hline No & $\begin{array}{l}\text { Nutritional } \\
\text { Composition }\end{array}$ & Unit & $\begin{array}{l}\text { Strawberry } \\
\text { Wet } \\
\text { Noodle }\end{array}$ & $\begin{array}{l}\text { No Strawberry } \\
\text { Wet Noodle }\end{array}$ & $\begin{array}{l}\text { Wet Noodle } \\
\text { In DKBM }\end{array}$ \\
\hline 1 & Energy & Kalori & 886,9 & 870,2 & 86 \\
\hline 2 & Protein & $\mathrm{g}$ & 26,8 & 20.1 & 0,6 \\
\hline 3 & Fat & $\mathrm{g}$ & 28,2 & 27,3 & 3,3 \\
\hline 4 & Carbohydrate & $\mathrm{g}$ & 116,8 & 114,6 & 14,0 \\
\hline 5 & Vitamin A & $\mathrm{SI}$ & 68,8 & 27,9 & 14 \\
\hline 6 & Vitamin B & $\mathrm{mg}$ & 4,9 & 0,0 & 0 \\
\hline 7 & Vitamin C & $\mathrm{mg}$ & 111,8 & 0.8 & 13 \\
\hline 8 & Calsium & $\mathrm{mg}$ & 45,5 & 23,9 & 0,8 \\
\hline 9 & Vitamin E & $\mathrm{mg}$ & 132,3 & 90,2 & 0 \\
\hline 10 & Phosporous & $\mathrm{mg}$ & 38,3 & 32,9 & 0 \\
\hline 11 & Zinc & $\mathrm{mg}$ & 3,4 & 2,8 & 0 \\
\hline 12 & Fiber & $\mathrm{g}$ & 6,1 & 3,9 & 80 \\
\hline
\end{tabular}

Source: Research Results Data of Making Strawberry Noodle, 2012

In table 2 the wet noodle nutrition content appeared on treatment $\mathrm{B}$ with the addition of strawberries than wet noodles without the addition of Strawberry treatment, wet noodles produced in research as well as a wet noodle that is made of reference standards (DKBM). In addition to the amount of energy generated and the content of all nutrients, especially vitamins and fiber is also higher compared to the wet noodle without strawberries. This is caused due to the addition of strawberries are rich in vitamins a can serve as natural antioxidants.

Protein content on a wet noodle of Strawberry is quite high compared to the other noodles. Protein is an important nutrients for the body, because this substance next to serves as a fuel in the body also serves as a builder and regulator (Winarno, 2004). The Level of protein Strawberry wet noodle produced in each treatment is $5.45 \%-6.06 \%$. Treatment A with the addition of Strawberry $50 \mathrm{~g}$, protein needs at the lowest levels in comparison with other treatments that of the $5.45 \%$ while treatment $\mathrm{B}$ with the addition of $100 \mathrm{~g}$ strawberries has protein level $6.01 \%$. At the treatment $\mathrm{C}$ by the addition of $150 \mathrm{~g}$ of strawberries has a $6.06 \%$ protein. The range of protein product of noodles according to SNI 01-2987-1992 is a minimum of $3 \%$. Results of the analysis of protein noodle indicates that levels of the protein at all treatment qualify of SNI.

The result analysis of fat level of wet noodles strawberries from the three treatments can be seen in table 1 . The range of the resulting levels of fat noodles is $0.60 \%$ $1.73 \%$. The highest fat content on the treatment $\mathrm{C}$ by the addition of $150 \mathrm{~g}$ strawberries amounted to $1.73 \%$, the lowest on the treatment A with the addition of $50 \mathrm{~g}$ strawberries amounted to $0.60 \%$ and next treatment B with the addition of $100 \mathrm{~g}$ strawberries range $0,69 \%$. Kind examination result indicates that the fat level of noodles do not differ markedly among the three treatments. Different formulations of the addition of Strawberry has no real effect to the fatlevel of strawberries wet noodle, this is because wheat flour is used has a low fat level.

Water Level influence on the store time and the texture of the product. Wet noodle has the store time relatively short because it has high water level which is about $47.50 \%$ $55,6 \%$. According to the Directorate of the Ministry of Health Nutrition 1992) cited by Astawan (2005), the nutritional composition of wet noodles per 100 grams of material that the energy $86 \mathrm{CAL}$, water $80 \mathrm{~g}$, carbohydrate $14 \mathrm{~g}$, fat $3,3 \mathrm{~g}$ and protein $0.6 \mathrm{~g}$. in addition to the advantages of the wet noodle, there is also a weakness, its store time relatively short i.e. 40 hours at room temperature due to the water content of wet noodles can reach $52 \%$. Kind Examination shows that the addition of strawberries on each different treatments in the strawberry wet noodle making influential to the water level of the product. This is because the strawberries also have high water levels around $89,9 \%$.

Most of the food materials, which is around $96 \%$ content of organic matter and water. The rest consists of mineral elements, also known as the dust levels. In the body mineral elements serve as a builder and regulator (Winarno, 2004). The range of dust levels noodle products according to SNI 01-2987-1992 is maximum $3 \%$. The lowest dust levels in the noodles with treatment $\mathrm{A}$ with the addition of $50 \mathrm{~g}$ strawberries around $0.67 \%$ and treatment B approximately $0.98 \%$, while the highest levels of dust on the noodles at the treatment $\mathrm{C}$ by the addition of Strawberry $150 \mathrm{~g}$. results of the analysis of dust levels of this noodle indicates that levels of dust in all treatment qualify of SNI.

Carbohydrates are the primary source of calories for almost the entire population of the world. Especially for the residents of the developing State. Carbohydrates also has an important role in determining the characteristics of the food such as taste, color, texture, and others (Winarno, 2004).

The range of levels of carbohydrate noodle products generated is $45,7841,44 \%-\%$

\section{F. Organoleptic Test}

The appeal of a type of food is affected by color as one of the components of the aesthetics and integral part in maintaining the quality of the wet noodle. Fine color and preferably of a product will encourage consumers to test other components sequencely to the aroma, texture and taste.From the organoleptic test against color, flavor, aroma, 
and texture of noodles to know the physical quality of noodles soaked strawberries can be seen in table 3 .

TABLE III

Average Values Of Organoleptic Test To The Color, Aroma, TEXTURE AND TASTE

\begin{tabular}{|c|l|l|l|l|l|l|}
\hline No & \multicolumn{1}{|c|}{ Treatment } & \multicolumn{3}{|c|}{ Average Values } & Criteria \\
\hline \multicolumn{2}{|c|}{} & Color & Aroma & Texture & Taste & \\
\hline 1 & $\begin{array}{l}\text { A (Strawberry } \\
50 \text { g) }\end{array}$ & 2.867 & 3.067 & 3.129 & 2.879 & $\begin{array}{l}\text { Less } \\
\text { Prefer }\end{array}$ \\
\hline 2 & $\begin{array}{l}\text { B (Strawberry } \\
100 \text { g) }\end{array}$ & 3.680 & 3.785 & 3.865 & 3.796 & Prefer \\
\hline 3 & $\begin{array}{l}\text { C (Strawberry } \\
150 \text { g) }\end{array}$ & 3.154 & 3.234 & 3.357 & 3.221 & Prefer \\
\hline 4 & D (Control) & 2.443 & 2.876 & 2.132 & 2367 & $\begin{array}{l}\text { Less } \\
\text { Prefer }\end{array}$ \\
\hline
\end{tabular}

Color in foods can be caused by a number of sources including pigments, the influence of heat on sugar (caramel), the reaction between sugars and amino acids (Maillard), and the presence of other ingredients mixing (Winarno, 1997). Color is the first impression caught panelists before recognizing the stimulus. Color is very important for any kind of food because it affects the level of acceptance of the panelists.

Assessment of the color parameter indicates that the wet noodle by the three treatments have almost the same value. It is supported from the results of the analysis of kind examination that the color of wet noodles do not differ markedly among the three treatments. It can be concluded that the panelists are somewhat like a wet noodle color of strawberries from by three treatments. This is because the color of Strawberry produced noodle is very interesting with a soft pink color that creates a new noodle color innovations.

Aroma is an important factor in determining the level of consumer acceptance in a material, the aroma of food deliciousness sets a lot, usually a person can assess whether or not a tasty food from the aroma caused. Assessment of the aroma in the table 3 shows that the strawberry wet noodle from the three treatments have almost the same value. Results of the kind examiniation analysis showed that the response of the panelists to the aroma of noodles that resulted is no real different. Panelists are somewhat like the aroma of noodles in each treatment i.e. the typical aroma of fresh noodles and the aroma of strawberries.

Taste is the sensation produced by material inserted into the mouth, felt the principle by the sense of taste in the mouth. According to Winarno (2004) taste is influenced by several factors, chemical compounds, temperature, concentration and interaction with other components of the flavor components of primary. Due to the increased intensity of the possible decrease in the intensity of taste or flavor (test compensation). Assessment of a wet noodle pointed out that the flavor of the three treatments have almost the same value. Results of the analysis of kind examination shows that the response of the panelists not real differ to the noodles taste from the three treatments.

The texture of a material is one of the important physical properties of foodstuffs. It is associated with the taste at the time to chew such materials (Rampengan, 1985). Texture is one of the important quality attributes, sometimes more important than the smell, taste, and color. Texture is the sensation of pressure that can be observed with the mouth (at the time being bitten, chewed, and swallowed) or groping with

fingers (Kartika, et all., 1988).Assessment of the texture of the noodles shows that dry noodle texture has the same assessment. The response of the panelists to the wet noodle texture not real differ between the three treatments.

\section{CONCLUSIONS AND SUGGESTIONS}

\section{A. CONCLUSIONS}

The concentration of the addition of Strawberry influential on the observed parameters. Especially treatment $\mathrm{B}$ with the addition of Strawberry $100 \mathrm{~g}$ compared with wet noodles without the addition of strawberries and control. Response of panelists to the organoleptic test include color, flavor, aroma and texture of strawberry wet noodles not real differ that is rather like between the three treatments.

\section{B. SUGGESTIONS}

One of the important parameters in the product of noodles is the elasticity associated with the texture of the noodles. Therefore, recommended that for further research conducted on test the elasticity of the strawberry wet noodle The paper will not be reformatted, so please strictly keep the instructions given above, otherwise it will be returned for improvement. Please upload your paper in PDF file through the Conference website under Paper Submission menu. Papers sent by e-mail will not be processed.

\section{REFERENCES}

[1] Gunawan, L.W.2000, Stroberi. Penebar Swadaya. Jakarta.

[2] Gunawan, A. 2007, "The Management of Acute Pulmonary Oedema in Ischemic Heart Disease". Asean Conference Medical Science. Medan.

[3] Hatma, R. D.2001. Nutrient Intake Relation to Lipid Profiles in Diverse Etnic Population and Their. Disertation Post Graduate Program University of Indonesia.

[4] Hasler, 1994, Familial and Diet induced Hypercholesrolemia in swine : lipid, Apo-1

[5] concentration and distributions in Plasma and Lipoprotein Subfractions, Arteriolscler. Trommb. 14 :923-936

[6] Wilkinson, Nancy. M. 2009, "Freeze dried Strawberry Powder Improves Lipid Profile and Lipid Peroxidation in Women With Metabolic Syndrome”. Oklahoma State University. USA. 